\title{
Points to Consider in Designing Mesenchymal Stem Cell-Based Clinical Trials
}

\author{
Gary Brooke $^{a}$ Tony Rossetti ${ }^{a}$ Nina llic ${ }^{b}$ Patricia Murray ${ }^{a}$ Sonia Hancock ${ }^{a}$ \\ Rebecca Pelekanos ${ }^{b}$ Kerry Atkinsona,b,c \\ a Mater Medical Research Institute, \\ b Mater Health Services, \\ c University of Queensland, Brisbane, Queensland, Australia
}

\section{Key Words}

Mesenchymal stem cells · MSC - Cell therapies .

Good manufacturing practice $\cdot$ Clinical trials

\section{Summary}

Therapeutic applications of cells are likely to increase greatly in the future. Cell and cell-based gene therapy manufacturing facilities need to be purpose-designed and accredited by their national medicinal regulatory body. Production scientists need to work in close tandem with quality assurance and ethics committees to absolutely ensure the safety of new cellular products. In this review, we consider the need for preclinical safety and efficacy data, tissue source for manufacture of clinical grade human mesenchymal stem cells, aseptic tissue processing, indemnification, and the role of the national medicinal regulatory body in appropriate clinical trial design.

\section{Introduction}

Mesenchymal stem cells (MSC) show great promise as a biological therapeutic cellular agent for a diverse range of unmet medical needs [1]. They are multipotent cells that can be derived from many different organs and tissues [2-7], and are (partially) characterised according to expression of the cell surface markers CD44, CD90, CD73, CD105, and CD166 [8]. MSC are relatively easy to isolate and expand in culture, and because of their multipotency, paracrine effects, immunomod-

\section{Schlüsselwörter}

Mesenchymale Stammzellen - MSC - Zelltherapien ·

Gute Herstellungspraxis · Klinische Studien

\section{Zusammenfassung}

Die therapeutische Anwendung von Zellen wird in der Zukunft stark zunehmen. Reinräume für Zell- bzw. zellbasierte Gentherapie müssen zweckentsprechend gestaltet und von der jeweiligen Aufsichtsbehörde zertifiziert sein. Wissenschaftler in der Produktion müssen eng mit der Qualitätskontrolle sowie den Ethikkommissionen zusammenarbeiten, um die Sicherheit neuer zellulärer Produkte zuverlässig zu gewährleisten. In diesem Übersichtsartikel beleuchten wir die Notwendigkeit von vorklinischen Sicherheits- und Effektivitätsdaten, Herkunftsgewebe für die Herstellung humaner mesenchymaler Stammzellen klinischer Qualität, aseptische Gewebebearbeitung, Schadensersatz sowie die Rolle der nationalen Bundesinstitute für Arzneimittel bei der Sicherstellung eines adäquaten klinischen Versuchsdesigns.

ulatory properties, migratory behaviour, and ethical considerations, they are likely to provide novel therapeutic alternatives in the 21st century.

When isolated by plastic adherence and expanded ex vivo, these cells have been shown to differentiate into cell types of mesodermal origin including chondrocytes, adipocytes, and osteocytes $[5,6]$. In addition to their mesodermal differentiation ability, MSC possess a greater plasticity in that they may be capable of differentiation into cells with characteristics of both ectodermal (neurons) and endodermal (hepatocytes) lineages

\begin{tabular}{ll}
\hline KARGER & $\odot$ 2008 S. Karger GmbH, Freiburg \\
Fax +4976145207 14 & Accessible online at: \\
$\begin{array}{l}\text { E-mail Information@Karger.de } \\
\text { www.karger.com }\end{array}$ & www.karger.com/tmh
\end{tabular}

\section{KARGER}

www.karger.com
Dr. Gary Brooke

Mater Medical Research Institute

Raymond Terrace,

South Brisbane, Queensland 4101 Australia

gbrooke@mmri.mater.org.au 
[9]. The multipotential properties and immuno-privileged ability gives them a major advantage over many other cell therapies in that in large outbred animals, including humans, they can be transplanted across major histocompatibility complex (MHC) barriers without the need for immune suppression [10]. Since tissue matching between MSC donor and recipient does not appear to be required, MSC appear be the first cell type able to be used as an 'off-the-shelf' therapeutic product. They can be mass-produced, cryopreserved, and shipped to medical facilities for immediate use in both acute and chronic disease settings. MSC have been reported in preclinical studies to improve myocardial function after myocardial infarction [11-14], liver damage [15], and lung damage [16]. Illustrative of these restorative abilities, several pre-clinical studies in the myocardial infarction model have reported that MSC attenuate maladaptive left ventricular (LV) remodelling, and preserve and/or promote recovery of pump performance after myocardial infarction. The mechanism underpinning these effects has been variously attributed to de novo cardiomyogenesis and neoangiogenesis. A growing body of evidence suggests, however, that the therapeutic effects of MSC transplantation primarily result from indirect stimulation (often termed paracrine) of neovascularisation, and protection from ischemia-induced apoptosis $[17,18]$.

Therapeutic application of MSC in humans has progressed as far as phase III clinical trials for the treatment of graft-versushost disease after bone marrow transplantation, and for the treatment of Crohn's disease. MSC are also in phase I clinical trials for the repair of myocardial damage after acute myocardial infarction, repair of non-healing bone fractures, and repair of meniscal tears. MSC are also a common starting material in many tissue engineering applications, exemplified by the production of osteo-inductive bone fragments and cartilage constructs. Thus, a plethora of potential therapeutic applications exist. Since MSC are derived postnatally (i.e., they are an 'adult' stem cell), their clinical application does not face the ethical challenges surrounding embryonic stem cells. Importantly, and unlike small molecule therapeutic agents, MSC and other cell types used in treatment are almost entirely manufactured in clinical facilities. Thus, for the first time, scientists producing theses agents need to be aware of, and diligent about, manufacturing these cells with high regard for the safety of the infused product. In this review we will consider the following points or questions:

- The need for in vitro and in vivo preclinical safety and efficacy data prior to initiating a clinical trial with human MSC.

- What is a safe, accessible and non-traumatic tissue source for the isolation and manufacturing of clinical grade human MSC?

- If a source other than bone marrow is utilised, how will it be harvested aseptically and the tissue processed prior to expansion on plastic surfaces?

- If a new source of MSC is to be utilised, what are the appropriate patient populations to be offered this product?
- What is the appropriate design for clinical trials involving human MSC?

- Role of the Institutional Ethics Review Board and the donor informed consent process.

- Role of the quality assurance program controlling MSC manufacturing.

- Need for indemnification by the clinical facility in which the trial is taking place.

- Role of the national medicinals regulatory body.

\section{Need for in vitro and in vivo Preclinical Safety and Efficacy Data Prior to Initiating a Clinical Trial with Human Mesenchymal Stem Cells}

MSC used for any clinical trial need to be characterised in terms of cell surface phenotype, differentiation potential, and immunosuppressive functional capacity. In vivo toxicity studies, at a minimum in mice, need to have been performed in a dose escalation manner. Efficacy data need to be available either from the Principal Investigator's laboratory or in the peer-reviewed medical and scientific literature.

\section{Production of Human Mesenchymal Stem Cells for Clinical Trials}

The ideal source of MSC for the clinic would be readily available, using a non-invasive harvesting procedure and yielding a large numbers of MSC for ex vivo expansion. MSC from tissues otherwise discarded, such as placenta, amniotic fluid, or liposuction fat, are an attractive alternative to bone marrow for large scale clinical production in the future.

\section{Isolation and Characterisation of MSC}

Several tissue sources of MSC have been studied that have potential for use in clinical trials. Historically, bone marrow has been the source tissue from which MSC have been derived [6]. Bone marrow was the first tissue in which MSC where identified [5], and isolation procedures for MSC from bone marrow have been well defined. More recently, other tissue sources have been suggested as a source of MSC including adipose tissue, placenta, and liver $[2-4,7,9,19]$. These may also be of use for clinical trials, and indeed may be preferable sources. At least in terms of use of allogeneic MSC in clinical trials, bone marrow isolation of MSC is still the most commonly used source $[10,20]$. Bone marrow-derived MSC have been shown to have both multipotent differentiation potential and powerful immunosuppressive qualities [21]. However, donation of bone marrow remains an invasive procedure requiring anaesthetic and significant risk and discomfort to the donor. An alternative source of donor bone marrow is that derived after orthopaedic surgery [22], a procedure that is generally carried 
out on older individuals. However, there may be considerable variation in 'quality' in terms of both expansion and differentiation potential of these cells [23], and therefore many potential donors may not be suitable. For these reasons, large scale collection of bone marrow for MSC use in the clinic is still difficult.

\section{What Is a Safe, Accessible, and Non-Traumatic Tissue Source for the Isolation and Manufacturing of Clinical Grade Human MSC?}

Placenta represents an alternative source of MSC that may be utilised in clinical trials. Placentas are a natural waste product at birth, and at the Mater Mother's Hospital, there are approximately 8,000 births per year, thus providing ample potential for donor tissue. We have therefore opted to use placental-derived MSC for our first clinical trial. Placental MSC show classical MSC phenotype and differentiation properties and potent immunosuppressive properties [24, 25]. In terms of manufacture of MSC from placenta, sterility of tissue at time of cell harvest is a major concern. We have opted for voluntary caesarean sections, as, although the operating procedures are open, they are performed in a relatively sterile environment. The placenta is subsequently double bagged in plastic draw string bags. After weighing, the placenta is placed in a cool box and transferred to our manufacturing facilities on the same campus for tissue processing.

Bone marrow MSC have been collected using standard density gradient procedures using Percoll ${ }^{\mathrm{TM}}$ (GE Healthcare, Uppsala, Sweden). However, Percoll is not produced as a good manufacturing practice (GMP) grade reagent. Ficoll-Paque Premium $^{\mathrm{TM}}$ (GE Healthcare), although more toxic to cells than Percoll, is manufactured under GMP conditions. We have found that Ficoll-Paque produces equivalent results for isolation of placental cells in our clinical trial (Rossetti et al., unpublished data). The absolute number of MSC present in the mononuclear cell prep is not known as there is still no reliable unique marker for MSC. However, we have found that in freshly isolated mononuclear placental cells, approximately $0.6 \%$ of cells are CD73+CD105+. However, the number of colony forming units (CFU) is considerably lower (unpublished observations). This is in line with the findings of others that have shown CFU to represent only $0.01-0.001 \%$ of mononuclear cells from bone marrow [6].

MSC can be greatly enriched from mononuclear cell preparations simply by selecting for rapidly proliferating plastic-adherent cells using standard media (e.g. Dulbecco's Modified Eagle Medium (DMEM)) and foetal calf serum (FCS). However, although this technique is good at removing contaminating leukocyte populations, it still yields a somewhat heterogeneous population with respect to the multipotency of mesenchymal stromal cells, such that when clones are isolated, they show mono-, di-, and tri-potentiality $[6,26]$. At present, there are no markers that can specifically isolate tri-potential MSC from cultured adherent stromal cells.

\section{If a Source Other than Bone Marrow Is Utilised, How Will} It Be Harvested Aseptically and the Tissue Processed prior to Manufacturing on Plastic Surfaces?

In terms of isolating MSC from tissues other than bone marrow for clinical trials, there has been a significant amount of pre-clinical work, and clinical trials are being initiated. There has been some variation in the types of tissue used and in the types of methods utilised to isolate MSC. Tissues used include cord blood, cord (Wharton's jelly), term and early trimester placenta, amniotic fluid, and amnion, and have all been reported as being sources of MSC [27, 28]. Placenta represents a particularly attractive source due to its ready availability. We have recently completed manufacture of $4.5 \times 10^{9}$ quality-controlled human MSC from 2 placentas for a Human Research Ethics Committee (HREC)-approved clinical trial to accelerate haematopoietic recovery after cord blood transplantation (fig. 1). Yen et al. [28] have reported using a flush/trypsin protocol for the isolation of MSC from term placenta. This is a very gentle method consisting of a PBS wash of placental pieces followed by a 10 -min incubation with $0.25 \%$ trypsin/ EDTA. Isolated cells were plated directly without a density gradient step. We have utilised a collagenase I-based protocol that requires tissue dissection, washing to remove excess cord blood, and incubation with collagenase I enzyme before isolation of cells. The major obstacles have been a lack of GMP grade reagents in the cell isolation steps, especially collagenase I. Collagenase I remains a crude isolation fraction containing a range of proteins and enzymes (e.g. collagenase, trypsin, and dispase). For future clinical production of MSC, a more defined mixture of recombinant enzymes may be required.

Although class II safety cabinets are used in the production of MSC, this still represents an 'open' system of manufacture. Even with a quality system in place and numerous safety precautions, there remains a greater chance of microbial contamination in an open system versus a closed system which would ideally be utilised. However, with the multiple steps required for isolation of MSC from placenta, an open system of cell isolation is still required at present.

Although small scale manufacture of MSC is possible, it represents a significant commitment of resources, both in terms of labour and materials. For our production runs, we initially seed eight $175-\mathrm{cm}^{2}$ tissue culture flasks (T175). After an initial expansion, the cells are passaged into 90 T175 flasks, which is the capacity of 1 cell culture incubator. When the flasks have just become confluent, the cells are detached from the flasks using TrypLE select ${ }^{\mathrm{TM}}$ (Invitrogen, Carlsbad, CA, USA), a GMP grade trypsin-like substitute. The majority of cells are then frozen, whilst a fraction of the cells are used to seed a further 90 flasks. This procedure is repeated 3 more times. Each passage of 90 flasks yields slightly less than 1 billion cells. The surface area represented by 90 flasks is $15,750 \mathrm{~cm}^{2}$, therefore at the time of passage, there were just over $6,000 \mathrm{cells} / \mathrm{cm}^{2}$. The cells are cultured in DMEM ( $1 \mathrm{~g} / \mathrm{l}$ glucose $)$ and $20 \%$ FCS. The 

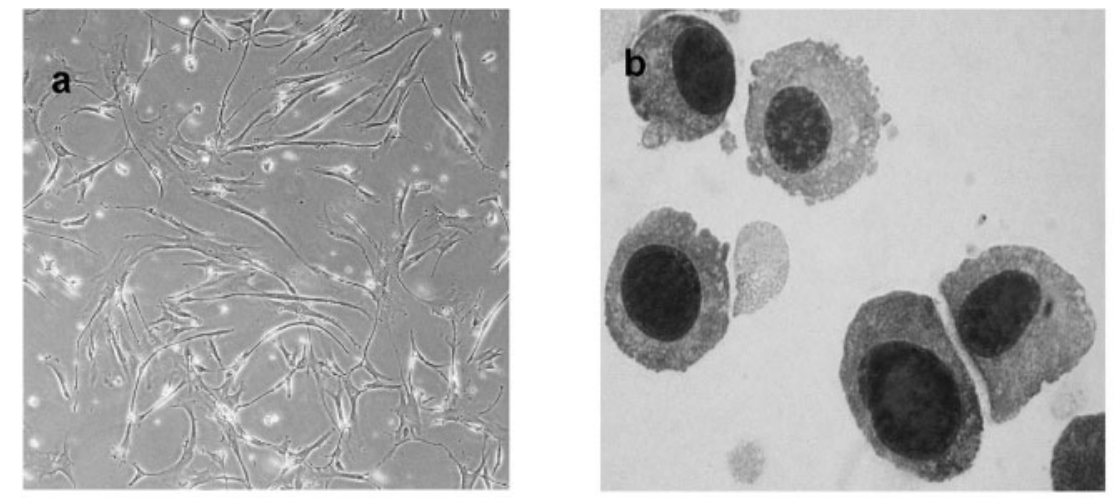

Fig. 1. Photomicrographs of a plastic adherent human MSC (phase contrast, 200×) and b Giemsa-stained cytospin of human MSC $(1,000 \times)$. c Forward and side scatter fluorescence-activated cell sorting (FACS) dot plot of human MSC. d Flow cytometry staining of passage human MSC showing positive staining for CD73 and CD105. CD45+ cells (leukocytes) constituted $0.4 \%$ at this time point.
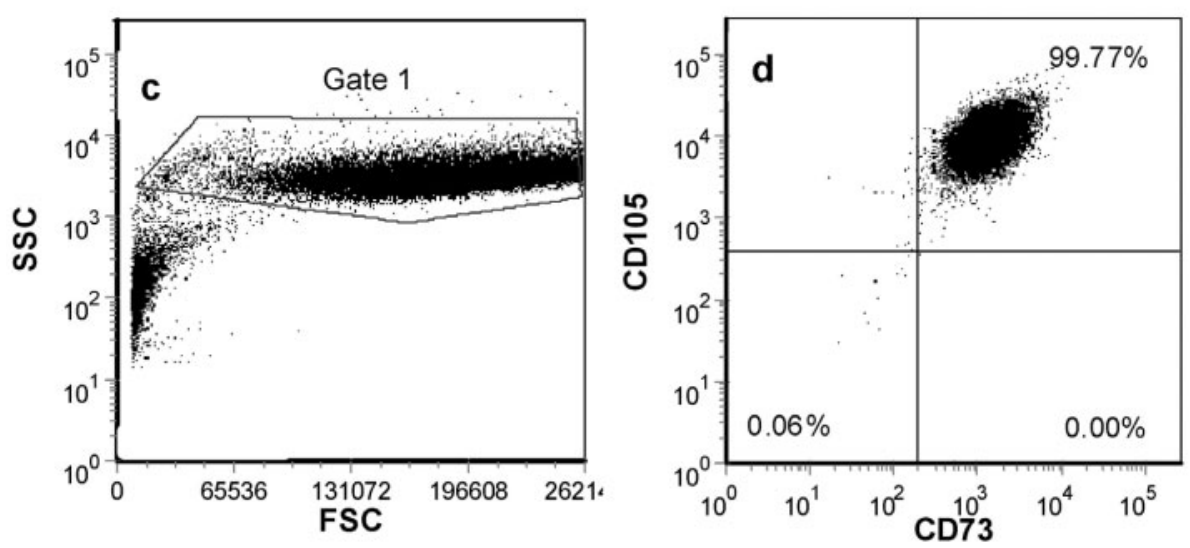

relatively high FCS concentration was used to maximise cell expansion rate [25]. The use of FCS is another risk factor that should be noted in clinical trials. FCS shows considerable variation in activity from batch to batch, and therefore in large scale production, large amounts of FCS may need to be reserved. The Australian Therapeutic Goods Authority (TGA) (equivalent of the FDA in the USA) allows the use of FCS for the production of clinical grade materials as long as it is sourced from cattle in a country free of bovine spongiform encephalitis such as Australia or New Zealand. However, ultimately, serum-free growth media would be preferred, and there have been recent additions to the market that may allow for this. We are currently testing these products. As well as production scientists involved in this manufacturing, we have a dedicated Cell Therapy Quality Management system in place to provide quality assurance of the manufacturing (see below).

The outcomes of our initial 2 manufacturing production runs generating MSC from 2 human placentas (which met quality release criteria) were $4.5 \leftrightarrow 10^{9}$ placenta-derived MSC cryopreserved; 97\% viability; Gram stain negative; endotoxin testing $<0.48 \mathrm{EU} / \mathrm{ml}$; sterile on 14-day culture of cell sample; flow cytometry CD45 negative, CD73/CD105 96\% double positive; and normal karyotype. These MSC have been transported to our collaborating hospital, Westmead Hospital Sydney, and the first patient received the infusion of human, unrelated, MHC-unmatched placenta-derived MSC in May 2008. As far as we are aware, this was the first time, placenta-derived MSC have been utilised clinically.

The current manufacturing process takes approximately $210 \mathrm{~h}$ with 3 production scientists to harvest and expand MSC from a single placenta. We are therefore now developing an automated process for the harvest and cultivation of MSC. A key challenge lies in the handling of large scale adherent cell cultures. We will utilise bioreactor technology. An integral feature of this approach is to develop a fully closed system compliant with current GMP. During production and preparation (manufacture) of our MSC for release, significant handling of the products occurs. Placentas must be collected from the birthing suite, packaged, and transported to the cell production facilities. Cells are manipulated multiple times during expansion. After cell production, cells must be transferred to cryostorage, and then transferred interstate before transplantation of the intended recipient. During these procedures, the product is manipulated, stored, transported, frozen, and thawed, thus providing multiple risk points for the product to be compromised.

\section{Patient Delivery Procedures for MSC in Clinical Trials}

MSC clinical trials in humans to date have used mostly bone marrow-derived MSC delivered via venous infusion [10, 20]. However, some groups have shown MSC can be safely infused into coronary arteries [29,30] and the spinal cord [31]. The doses of MSC given generally range from $1 \times 10^{6} / \mathrm{kg}$ to 10 
$\times 10^{6} / \mathrm{kg}$, and no acute infusion-related toxicity has been observed at these doses. Although there is no widely accepted standard for cryopreservation, storage, thawing, and infusion of MSC therapies, our group has adhered to a combination of standards from early MSC trials and current practices in other clinical stem cell processes. MSC are cryopreserved in cord blood cryobags using a controlled rate freezer, ramping from 0 to $-90{ }^{\circ} \mathrm{C}$ in $1.5 \mathrm{~h}$. Numerous options for cryopreservation solution are available from the simple clinical human serum albumin (HSA) and 10\% dimethyl sulfoxide (DMSO) to a commercially prepared product such as Cryostore. We have chosen to use approximately 5\% HSA, 10\% DMSO in Hanks Balanced Salt Solution. The MSC are then stored in vapour phase liquid nitrogen storage vessels until all release criteria testing has been finalised and approved. Once released from manufacturing, the MSC can be shipped to clinical sites in a validated 'dry shipper' capable of holding the temperature below $-130{ }^{\circ} \mathrm{C}$ for up to 5 days. The thawing procedure for venous infusion of MSC is rapid. The cryobag is double bagged and thawed in a $39{ }^{\circ} \mathrm{C}$ water bath at the patients bedside. Patients are pre-medicated with an antipyretic and antihistamine (acetaminophen and diphenhydramine hydrochloride) to minimise any DMSO infusion toxicity [20]. When the cell product is almost completely thawed, the cells are gravity-infused at a slow rate $(5 \mathrm{ml} / \mathrm{min})$ until the required cell dose is achieved.

\section{Quality System and Controlled Process}

\section{Role of the Quality Assurance Program Controlling MSC Manufacturing}

In order to minimise risks to the product and maximise safety of patients and staff, and also to comply with the requirements of the HREC, a Quality System was established at the Mater Health Services/Mater Medical Research Institute in June 2005. The main objective of the Quality System was to provide support in order to comply with national and international standards, such as GMP for Blood and Tissues by the Australian TGA and other applicable standards. As part of the Quality System, an extensive document control system has been developed and implemented in order to comply with GMP requirements. It covers relevant protocols, procedures, and other related documentation. The Quality System implemented in collection, processing, storage, and release, also addresses the following elements: i) facilities (design, access, and maintenance); ii) equipment (purchase, use, and maintenance); iii) materials (specifications, purchase, storage, and use); and iv) quality assurance (quality control, validation, qualification, and document control).

We have established a formal training system which includes learning modules, training, and assessment, as well as continuing education for staff. An efficient and robust system of reporting and addressing of non-conformances (non-compli- ances with external or internal requirements), improvement suggestions, and change control has been established. The Quality System staff conducts regular internal audits and audits of third parties, while providing relevant follow-up of nonconformances, recommendations, and consultancy to stakeholders. In areas where the Quality System interacts with hospital departments and infrastructure, such as housekeeping, engineering, information technology, and supply department, the aim is to establish relevant service level agreements in order to ensure adequate level of regulatory compliance.

The Quality System approach is risk-based. It builds up on the multidisciplinary team expertise, while founded on the following elements: quality program, organisation and personnel, standard operating procedures, facilities, environmental control, equipment monitoring, supplies and reagents, process controls, process changes, process validation, labelling design and control, storage requirements, records, tracking, non-conformances and complaints management, risk assessment, reporting and reviewing.

\section{What Is the Appropriate Design for Clinical Trials Involving Human MSC?}

Clinical trials using new sources of MSC should be initiated as phase I trials. Clinical trials using cells that have been used in phase I but are now being used in a different clinical setting may be initiated as phase I/II clinical trials. In this setting, a placebo-controlled double-blind trial design has significant value. A Data Safety Monitoring Board is strongly recommended. Phase I trials with MSC should focus primarily on safety endpoints such as acute infusional toxicity, increase in incidence of infection or of malignancy (because of the immune suppressive capacity of MSC), and occurrence of ectopic tissue formation (because of the ability of MSC to differentiate into bone, cartilage, or fat tissue). Thus, monitoring of the recipient's vital signs is important for at least $4 \mathrm{~h}$ after MSC infusion. In our clinical trial program, we check for the possibility of ectopic tissue formation using computed tomography (CT) scanning of the chest, abdomen, and pelvis at 3,12, and 24 months after MSC infusion. Phase I trials can also be used for MSC dose-finding studies. Phase II studies explore efficacy endpoints such as the potential acceleration of haematopoietic engraftment after umbilical cord blood transplantation if MSC are co-transplanted with cord blood cells, or change in cardiac function if MSC are administered after an acute myocardial infarction. Phase III studies determine the efficacy of MSC compared to the current best standard practice. All trials need to be powered with a sufficient number of patients to allow a conclusion to be made with regard to the clinical aim being tested. It is also of scientific importance to determine if MSC survive after transplantation. This can be assessed using HLA typing of appropriate target organs or of the bone marrow if allogeneic, unrelated, MHC-unmatched MSC are used. Unrelated volunteer donors are currently the most common source of MSC for clinical trials. 


\section{If a New Source of MSC Is to Be Utilised, What Are the} Appropriate Patient Populations to Be Offered This Product? All new experimental agents that are delivered systemically should involve patient populations who are at significant risk of morbidity or mortality with conventional treatment. A balance between potential benefit and potential unknown side effects must be achieved using a fully transparent, ethically valid informed consent process.

\section{Role of the Institutional Ethics Review Board and the Donor Informed Consent Process}

Involvement of the Institutional Ethics Review Board is essential and integral to MSC trials, as they are to the evaluation and development of any other experimental therapeutic agent.

\section{Need for Indemnification by the Clinical Facility in which the Trial Is Taking Place}

Indemnification by the insurers of the medical facility in which the trial is taking place is essential for the safety of the donors, patients, staff, and the facility itself.
Role of the National Medicinal Regulatory Body

Likewise, the national medicinal regulatory body should be aware of the initiation of the clinical trial before it starts.

\section{The Future}

Therapeutic applications of in vitro manipulated cells represents an exciting and growing field. Cell and cell-based gene therapy manufacturing facilities need to be purpose-designed, and will need to be accredited by their national medicinal regulatory body. Production scientists need to work in close tandem and harmony with quality assurance and ethics committees to absolutely ensure the safety of new cellular products.

\section{Acknowledgements}

This work was funded by the Mater Foundation and Inner Wheel Australia.

\section{References}

1 Brooke G, Cook M, Blair C, Han R, Heazlewood C, Jones B, Kambouris M, Kollar K, McTaggart S, Pelekanos R, Rice A, Rossetti T, Atkinson K: Therapeutic applications of mesenchymal stromal cells. Semin Cell Dev Biol 2007;18:846-858.

$\checkmark 2$ Campagnoli C, Roberts IA, Kumar S, Bennett PR, Bellantuono I, Fisk NM: Identification of mesenchymal stem/progenitor cells in human firsttrimester fetal blood, liver, and bone marrow. Blood 2001;98:2396-2402.

- 3 Erices A, Conget P, Minguell JJ: Mesenchymal progenitor cells in human umbilical cord blood. $\mathrm{Br}$ J Haematol 2000;109:235-242.

4 In 't Anker PS, Scherjon SA, Kleijburg-van der Keur C, de Groot-Swings GM, Claas FH, Fibbe WE, Kanhai HH: Isolation of mesenchymal stem cells of fetal or maternal origin from human placenta. Stem Cells 2004;22:1338-1345.

5 Owen M, Friedenstein AJ: Stromal stem cells: marrow-derived osteogenic precursors. Ciba Found Symp 1988;136:42-60.

6 Pittenger MF, Mackay AM, Beck SC, Jaiswal RK, Douglas R, Mosca JD, Moorman MA, Simonett DW, Craig S, Marshak DR: Multilineage potential of adult human mesenchymal stem cells. Science 1999;284:143-147.

7 Yoshimura K, Shigeura T, Matsumoto D, Sato T, Takaki Y, Aiba-Kojima E, Sato K, Inoue K, Nagase T, Koshima I, Gonda K: Characterization of freshly isolated and cultured cells derived from the fatty and fluid portions of liposuction aspirates. J Cell Physiol 2006;208:64-76.

$>8$ Dominici M, Le Blanc K, Mueller I, Slaper-Cortenbach I, Marini F, Krause D, Deans R, Keating A, Prockop D, Horwitz E: Minimal criteria for defining multipotent mesenchymal stromal cells. The international society for cellular therapy position statement. Cytotherapy 2006;8:315-317.

$\checkmark 9$ Lee OK, Kuo TK, Chen WM, Lee KD, Hsieh SL, Chen TH: Isolation of multipotent mesenchymal stem cells from umbilical cord blood. Blood 2004; 103:1669-1675.
10 Le Blanc K, Frassoni F, Ball L, Locatelli F, Roelofs H, Lewis I, Lanino E, Sundberg B, Bernardo ME, Remberger M, Dini G, Egeler RM, Bacigalupo A, Fibbe W, Ringden O: Mesenchymal stem cells for treatment of steroid-resistant, severe, acute graftversus-host disease: a phase ii study. Lancet 2008; 371:1579-1586.

11 Berry MF, Engler AJ, Woo YJ, Pirolli TJ, Bish LT, Jayasankar V, Morine KJ, Gardner TJ, Discher DE, Sweeney HL: Mesenchymal stem cell injection after myocardial infarction improves myocardial compliance. Am J Physiol Heart Circ Physiol 2006; 290:H2196-203.

12 Kinnaird T, Stabile E, Burnett MS, Shou M, Lee CW, Barr S, Fuchs S, Epstein SE: Local delivery of marrow-derived stromal cells augments collateral perfusion through paracrine mechanisms. Circulation 2004;109:1543-1549.

13 Silva GV, Litovsky S, Assad JA, Sousa AL, Martin BJ, Vela D, Coulter SC, Lin J, Ober J, Vaughn WK, Branco RV, Oliveira EM, He R, Geng YJ, Willerson JT, Perin EC: Mesenchymal stem cells differentiate into an endothelial phenotype, enhance vascular density, and improve heart function in a canine chronic ischemia model. Circulation 2005;111: 150-156.

14 Tomita S, Mickle DA, Weisel RD, Jia ZQ, Tumiati LC, Allidina Y, Liu P, Li RK: Improved heart function with myogenesis and angiogenesis after autologous porcine bone marrow stromal cell transplantation. J Thorac Cardiovasc Surg 2002;123:1132-1140.

15 Lee KD, Kuo TK, Whang-Peng J, Chung YF, Lin CT, Chou SH, Chen JR, Chen YP, Lee OK: In vitro hepatic differentiation of human mesenchymal stem cells. Hepatology 2004;40:1275-1284.

16 Ortiz LA, Gambelli F, McBride C, Gaupp D, Baddoo M, Kaminski N, Phinney DG: Mesenchymal stem cell engraftment in lung is enhanced in response to bleomycin exposure and ameliorates its fibrotic effects. Proc Natl Acad Sci U S A 2003;100: 8407-8411.
17 Gnecchi M, He H, Liang OD, Melo LG, Morello F, Mu H, Noiseux N, Zhang L, Pratt RE, Ingwall JS, Dzau VJ: Paracrine action accounts for marked protection of ischemic heart by akt-modified mesenchymal stem cells. Nat Med 2005;11:367-368.

18 Jiang S, Haider H, Idris NM, Salim A, Ashraf M: Supportive interaction between cell survival signaling and angiocompetent factors enhances donor cell survival and promotes angiomyogenesis for cardiac repair. Circ Res 2006;99:776-784.

19 Wang HS, Hung SC, Peng ST, Huang CC, Wei HM, Guo YJ, Fu YS, Lai MC, Chen CC: Mesenchymal stem cells in the wharton's jelly of the human umbilical cord. Stem Cells 2004;22:1330-1337.

20 Lazarus HM, Koc ON, Devine SM, Curtin P, Maziarz RT, Holland HK, Shpall EJ, McCarthy P, Atkinson K, Cooper BW, Gerson SL, Laughlin MJ, Loberiza FR, Jr., Moseley AB, Bacigalupo A: Cotransplantation of hla-identical sibling culture-expanded mesenchymal stem cells and hematopoietic stem cells in hematologic malignancy patients. Biol Blood Marrow Transplant 2005;11:389-398.

21 Le Blanc K, Tammik L, Sundberg B, Haynesworth SE, Ringden O: Mesenchymal stem cells inhibit and stimulate mixed lymphocyte cultures and mitogenic responses independently of the major histocompatibility complex. Scand J Immunol 2003;57:11-20.

22 Suva D, Garavaglia G, Menetrey J, Chapuis B, Hoffmeyer P, Bernheim L, Kindler V: Non-hematopoietic human bone marrow contains long-lasting, pluripotential mesenchymal stem cells. J Cell Physiol 2004;198:110-118.

23 Mareddy S, Crawford R, Brooke G, Xiao Y: Clonal isolation and characterization of bone marrow stromal cells from patients with osteoarthritis. Tissue Eng 2007;13:819-829.

24 Jones BJ, Brooke G, Atkinson K, McTaggart SJ: Immunosuppression by placental indoleamine 2.3dioxygenase: A role for mesenchymal stem cells. Placenta 2007;28:1174-1181. 
25 Barlow S, Brooke G, Chatterjee K, Price G, Pelekanos R, Rossetti T, Doody M, Venter D, Pain S, Gilshenan K, Atkinson K: Comparison of human placenta- and bone marrow-derived multipotent mesenchymal stem cells. Stem Cells Dev, in press.

26 Gronthos S, Zannettino AC, Hay SJ, Shi S, Graves SE, Kortesidis A, Simmons PJ: Molecular and cellular characterisation of highly purified stromal stem cells derived from human bone marrow. J Cell Sci 2003;116:1827-1835.

27 Romanov YA, Svintsitskaya VA, Smirnov VN Searching for alternative sources of postnatal human mesenchymal stem cells: candidate msc-like cells from umbilical cord. Stem Cells 2003;21: 105-110.

28 Yen BL, Huang HI, Chien CC, Jui HY, Ko BS, Yao M, Shun CT, Yen ML, Lee MC, Chen YC: Isolation of multipotent cells from human term placenta. Stem Cells 2005;23:3-9.

29 Strauer BE, Brehm M, Zeus T, Kostering M, Hernandez A, Sorg RV, Kogler G, Wernet P: Repair of infarcted myocardium by autologous intracoronary mononuclear bone marrow cell transplantation in humans. Circulation 2002;106:1913-1918.

30 Chen SL, Fang WW, Ye F, Liu YH, Qian J, Shan SJ, Zhang JJ, Chunhua RZ, Liao LM, Lin S, Sun JP: Effect on left ventricular function of intracoronary transplantation of autologous bone marrow mesenchymal stem cell in patients with acute myocardial infarction. Am J Cardiol 2004;94:92-95.

31 Mazzini L, Fagioli F, Boccaletti R, Mareschi K, Oliveri G, Olivieri C, Pastore I, Marasso R, Madon E: Stem cell therapy in amyotrophic lateral sclerosis: A methodological approach in humans. Amyotroph Lateral Scler Other Motor Neuron Disord 2003:4:158-161. 